\title{
Economics and health - how does 2015 look?
}

T he current discussion about copayments illustrates how hard it is to make sense of the interplay of the health and economic systems, especially when political wheels are engaged. When the copayment was proposed it was said to be necessary because the health service was unsustainable. Its purpose changed on the night of the presentation of the 2014 federal Budget, to funding medical research. Later it became a price signal, despite already obvious price signals in the form of private health insurance premiums and the Medicare levy.

Our complex and large contemporary health and economic systems interact frequently. Concerns about the cost of health care are commonplace; and likewise, fears about the way in which health is determined by the economic climate in a country are frequently expressed by public health professionals. Somewhere in the machinery connecting health and economics another set of cogs and wheels clicks in - politics.

\section{"The discourse about Australian economics does not always take account of what is happening globally"}

At national and international levels the power of economics on health is also immense. At the beginning of 2015 it is wise to look at how the world economy is likely to perform, because this will determine the resources available to us for health care and influence the social environment here and abroad.

In an article titled Past and future tense in The Economist of 20 December 2014, the author explores three trends in the global economy. Looking like a replay of the late 1990s, when the world began to pull away from the burst dotcom bubble - a period similar to the current post-global financial crisis period - these trends could affect us all.

First, he or she identifies "the gap between America, where growth is accelerating, and almost everywhere else, where it is slowing". Nevertheless, a stronger dollar, while beneficial to many Americans, does not help their exporters, so comfort in the United States will not be evenly distributed.

The second trend is a "dismal outlook for the rich world's two other big economies" - Germany and Japan. Germany stands to lose, in the opinion of the author of Past and present tense, because of a slow growth rate $(1 \%)$ and a "deeper malaise caused by years of underinvestment, a disastrous energy policy and a government that is too obsessed by its fiscal targets to spend money and too frightened of voters" to push through necessary structural reforms. Japan "has repeated the error it made in 1997" by prematurely raising its consumption tax, "thwarting its escape from stagnation". Not much help is likely from either Germany or Japan.

The third current trend towards destabilisation of the world economy that resembles what was seen in the 1990 s is what is happening in developing economies, in Africa especially. Then, fixed exchange rates and huge foreign debts were the problem. Now, it is falling commodity prices. Oil comprises $95 \%$ of Nigeria's exports, the article states. How does health care fare when the oil price is halved? Would Nigeria now, this year, be able to handle Ebola as efficiently as it did in 2014?

A major change between now and the late 1990s has been the rise of China. China's increased wealth may serve as a buffer to many nations.

But "add all this up", the article states, "and 2015 seems likely to be bumpy". The US Federal Reserve Bank has little room to move, and with interest rates hovering around zero, there is little that such banks can do to stimulate economies.

"All over the rich world voters are already grumpy with their governments ... If they are squeezed [in 2015] discontent will turn to anger. The economics of 2015 may look similar to the late 1990s, but the politics will probably be rather worse."

The discourse about Australian economics does not always take account of what is happening globally, and concentrates on the errors of politicians and decisionmakers who came before. It is important to be aware of the economic trends and determinants that set the level of our national wealth (and hence the amount available for health care) and be as prepared as we can be for the health consequences of economic forces on the health of the citizens we treat.

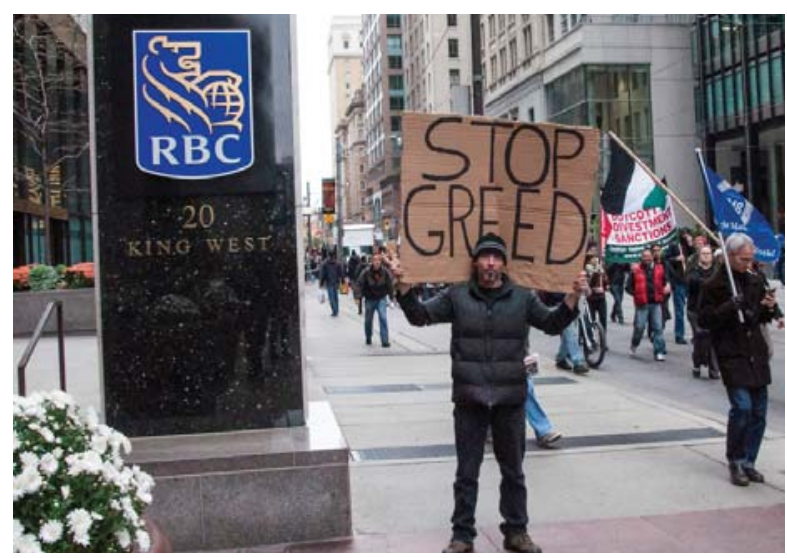

A protester poses next to a Royal Bank of Canada sign, as part of the international Occupy movement, which protests against economic inequality, corporate greed, and the influence of corporations and lobbyists on government. 